\title{
Northern Ireland: Is the Peace Process Really Under Threat?
}

Irlande du Nord: un processus de paix menacé?

\section{Michel Savaric}

\section{(2) OpenEdition}

\section{Journals}

\section{Electronic version}

URL: http://journals.openedition.org/rfcb/1997

DOI: $10.4000 /$ rfcb. 1997

ISSN: 2429-4373

\section{Publisher}

CRECIB - Centre de recherche et d'études en civilisation britannique

\section{Electronic reference}

Michel Savaric, « Northern Ireland: Is the Peace Process Really Under Threat? », Revue Française de Civilisation Britannique [Online], XXIII-2 | 2018, Online since 14 September 2018, connection on 03 May 2019. URL : http://journals.openedition.org/rfcb/1997; DOI : 10.4000/rfcb.1997

This text was automatically generated on 3 May 2019.

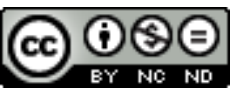

Revue française de civilisation britannique est mis à disposition selon les termes de la licence Creative Commons Attribution - Pas d'Utilisation Commerciale - Pas de Modification 4.0 International. 


\title{
Northern Ireland: Is the Peace Process Really Under Threat?
}

Irlande du Nord: un processus de paix menacé?

\author{
Michel Savaric
}

\section{Introduction}

1 In April 2017, when Theresa May called for a general election, the BBC interviewed Brenda, an elderly resident from Bristol who seemed to sum up the general mood of British people: "You're joking. Not another one!" she exclaimed. ${ }^{1}$ The video became viral. In Northern Ireland, this feeling of exasperation could have been even more pronounced since this was the fourth election in just over a year. However, the impact of the Brexit vote should not be neglected. Election fatigue was counter-balanced by the issues at stake: the prospect of a 'hard border' between both parts of Ireland, calls for a border poll, hopes for a united Ireland, the fear of a break-up of the United Kingdom. This could explain why there seemed to be a renewed interest in politics, marked first by the high turnout at the $2^{\text {nd }}$ March local assembly election. This renewed interest was expressed through the traditional sectarian divide: people voted either for the Democratic Unionist Party or for Sinn Féin.

2 In June, the DUP attracted an unprecedented amount of media attention in Britain and even worldwide. While the locally published Irish News revealed that "'who are the DUP?' was the most asked question on Google", ${ }^{2}$ Le Monde took an interest, even translating its acronym into French: "Le PUD, le petit parti nord-irlandais qui permet à Theresa May d'avoir une majorité absolue". ${ }^{3}$ For the Huffington Post, the DUP was "[un] petit parti sulfureux". ${ }^{4}$ The Guardian informed its readers about "Six DUP Stances You Should Know About ${ }^{5 "}$. The Independent, highlighting the same contentious topics as The Guardian (abortion, gay marriage, climate change), wondered "Why is the DUP so controversial?" The Telegraph went as far as presenting each of the ten newly elected (or re-elected) DUP Members of Parliament, emphasizing their support for the death penalty, creationism and their 
opposition to abortion rights.7 The Daily Mail voiced its concerns over "whether Mrs May should be striking a deal with a party whose former leaders flirted with loyalist paramilitaries". ${ }^{8}$

\section{Nothing new about the DUP}

3 For people in Northern Ireland, the fact that the British and international press suddenly discovered the party which had been in power for ten years seemed strange. It all but confirmed their position as the most peripheral part of the United Kingdom. There is indeed nothing new about the Democratic Unionist Party. Historically, this party cannot be separated from the personality of Ian Paisley who founded it in 1971 when the Troubles were still in their infancy. Paisley himself had one of the longest careers among European politicians. He gained notoriety during the 1964 general election campaign when he led a march, which turned into a riot, to have an Irish tricolour removed from the window of an independent republican candidate office in West Belfast (Sinn Féin was banned at the time). When Terence O'Neill, the Northern Ireland Prime Minister of the time who was deemed too liberal and lenient towards Catholics, invited Taoiseach Sean Lemass, a former IRA veteran, in January 1965, Paisley threw snowballs at his car. Then of course he played a prominent role leading counter-demonstrations during the civil rights campaign. At the time, in the 1960s, this fire-brand preacher with a booming voice who equated anarchism, communism, republicanism with Catholicism did seem like an oddity.

But over the years, Paisley became a permanent fixture of Northern Ireland, an archetypal figure. People used to tell "Paisley jokes", references to him abound in literature. For example, John Hewitt dedicated a poem entitled "Demagogue" to him which contained these verses:

Compulsive preacher, large, and loud of voice

in octaves of abuse, invective, hate;

a Samson self-ordained, his strength destroys

whatever justified our canting state,

since his chief skill is to articulate

the smouldering terrors and the prejudice

that makes our heritage a dubious freight

which, now exposed, is seen for what it is. ${ }^{9}$

Ian Paisley has also inspired characters or appeared under his real name in many novels. He died in 2014 at the age of 88 but his image had undergone a major change. In 2006, he agreed to share power with Sinn Féin, formerly the political wing of the IRA, his most reviled enemies. From troublemaker, Paisley became a peacemaker. ${ }^{10} \mathrm{He}$ even struck up a friendship with his Deputy First Minister Martin McGuinness, which earned them the nickname 'Chuckle Brothers'. ${ }^{11}$

In 1998, when the Belfast (or Good Friday) agreement was negotiated, the DUP refused to sign it. But in 2006, they signed the Saint Andrews agreement whereby they agreed to share power with Sinn Féin in return for them recognising the legitimacy of the police. Ever since the (Northern) Irish question resurfaced at the end of the 1960s, finding an internal solution to it had been the ultimate goal of successive British governments. Initially, the 1998 Belfast agreement was designed, like all previous attempts, to work with the middle-ground of Northern Irish politics: the 'moderate' unionists of the UUP (Ulster Unionist Party) and the 'constitutional'12 nationalists of the SDLP (Social Democratic and Labour Party). But from 2003 onward, support for the moderates began to 
wane. The DUP and Sinn Féin became the two dominant parties. Several prominent members of the UUP defected to the DUP, including Jeffrey Donaldson who, on the night of 8 June, was jubilant ("This is perfect territory for the DUP obviously because if the Conservatives are just short of an overall majority, it puts us in a very, very strong negotiating position and it is one we would take up with relish" he told the $\mathrm{BBC})^{13}$ and current First Minister Arlene Foster. The DUP and Sinn Féin were re-elected to the devolved assembly in 2007, 2011, 2016 and 2017. In the House of Commons, the UUP lost all of its seats in 2010 , regained two in 2015 , lost them again in 2017. The SDLP found itself without seats in 2017.

\section{Paradoxes of the DUP-SF partnership}

7 Paradoxically the institutions put in place in 1998 only began to effectively function under the DUP-Sinn Féin coalition. The parties seen as extremist brought stability to Northern Ireland. Between 1998 and 2007, the Northern Ireland assembly had been suspended several times: it first met on 1 July 1998 but only existed in shadow form until 2 December 1999. Direct rule was reintroduced from 11 February to 30 May 2000, on 10 August and 22 September 2001 for 24 hours only, then between 14 October 2002 and 7 May 2007. Certainly, Northern Ireland continued to be rocked by major controversies, political crises and scandals after 2007 but the assembly and the executive worked uninterruptedly for 10 years until Martin McGuinness's resignation on 10 January 2017.

Among the many political scandals that have punctuated the last ten years, a number of them involved the DUP, contradicting its stance as the most puritan political party in Northern Ireland. Yet, the party retained its strident opposition to the secularisation of society, such as same-sex marriages or the right to abortion and even promoted the teaching of creationism. These positions probably have to be seen as the ultimate remnants of its uncompromising past, for it has given up on what mattered most: its absolute refusal to negotiate anything with Catholics, with nationalists and republicans. The DUP's electoral successes are then paradoxical in many respects. The gradual shift of Protestant voters towards the DUP showed growing disaffection for the Belfast agreement. Yet, the DUP helped secure the Northern Ireland assembly and the powersharing executive. Voters should logically have spurned it but it has managed to remain at the top of every poll since 2003. However, in 2011, turnout was low: $55.71 \%$, which may be read as an expression of defiance at the DUP-Sinn Féin partnership from the electorate. The May 2016 local assembly election showed little change but turnout was even lower, the lowest ever since 1998: 54.91\%. All of the main parties lost votes but nationalists' disaffection seemed more pronounced than unionists'. Sinn Féin's share of the vote was down $2.9 \%$ and the SDLP lost $2.2 \%$. The two main unionist parties retained the same number of seats with 54 ( 38 for the DUP and 16 for the UUP) while the nationalists were down three seats with 28 for Sinn Féin $(-1)$ and 12 for the SDLP $(-2)$. Two small parties, further to the left of the political spectrum, made gains: People Before Profit, which won two seats for the first time, even topping the poll in the Belfast West constituency, and the Green Party.

Table 1: Northern Ireland Assembly election (5 May 2016) overall results ${ }^{14}$

\begin{tabular}{|l|l|l|l|l|l|}
\hline Affiliation & Votes $\left(1^{\text {st }}\right.$ pref.) & Share & $+/-\%$ (from 2011$)$ & Seats & Gain/Loss \\
\hline
\end{tabular}




\begin{tabular}{|l|l|l|l|l|l|}
\hline DUP & 202,567 & 29.2 & -0.8 & 38 & - \\
\hline SF & 166,785 & 24.0 & -2.9 & 28 & -1 \\
\hline UUP & 87,302 & 12.6 & -0.7 & 16 & - \\
\hline SDLP & 83,638 & 12.0 & -2.2 & 12 & -2 \\
\hline APNI & 48,447 & 7.0 & -0.7 & 8 & - \\
\hline TUV & 23,776 & 3.4 & +0.9 & 1 & - \\
\hline Green & 18,718 & 2.7 & +1.8 & 2 & +1 \\
\hline PBPA & 13,761 & 2.0 & +1.2 & 2 & +2 \\
\hline UKIP & 10,109 & 1.5 & +0.8 & 0 & - \\
\hline PUP & 5,955 & 0.9 & +0.6 & 0 & - \\
\hline Conservative & 2,554 & 0.4 & +0.4 & 0 & - \\
\hline Independent & 22,650 & 3.3 & +0.9 & 1 & - \\
\hline Others & 8,322 & 1.2 & & - \\
\hline Total & 694,314 & 100.0 & & 08 & \\
\hline
\end{tabular}

Source: Irish Political Studies, "Data Yearbook 2017", Vol. 32, Issue 4, Dec. 2017 , p. 529.

9 At the same time as the Stormont election campaign was taking place, political parties were also preparing for the EU referendum. On $20^{\text {th }}$ February, the DUP decided to campaign for a Leave vote. It had chosen to align itself with UKIP. It was the only major Northern Ireland party to do so. The UUP had decided to back the Remain campaign, along with the two main nationalist parties. On $11^{\text {th }}$ March, Sinn Féin's Martin McGuinness called for a border poll if the UK voted to leave the EU. ${ }^{15}$ Such a position could be seen as strange since, by campaigning for a Remain vote, it was actually campaigning against a referendum on Irish unity. But this was the same position as the one taken by the Scottish Nationalist Party (SNP).

The border issue was the main focus of concern during this campaign. The checkpoints between Northern Ireland and the Republic of Ireland used to be part of the most militarised zone in Europe. With the peace process, controls were gradually suppressed so that today, travellers move from one jurisdiction to the next without almost realising it. The border issue is linked to the partition of Ireland, a topic which used to be hotly debated and contested but had seemed to become less relevant in recent times. On $10^{\text {th }}$ February, Irish Ambassador to the UK Dan Mulhall was invited to address the House of Commons' Northern Ireland Affairs Committee. He argued that if Britain voted to leave the EU, it would create uncertainty about the border between Northern Ireland and the Republic. ${ }^{16}$ On $6^{\text {th }}$ June, Chancellor of the Exchequer George Osborne came to Belfast to campaign for a Remain vote. He stated that should the UK leave the EU, border checks 
would become inevitable. Then on $9^{\text {th }}$ June, former Prime Ministers Tony Blair and John Major made a joint appearance at the University of Ulster and warned that Brexit could lead to the disintegration of the United Kingdom.

11 The vote took place on $23^{\text {rd }}$ June. The gap was narrower than the $70 / 30$ which polls had predicted at the start, but Northern Ireland voted by $55.8 \%$ to remain in the European Union. We can try and analyse voters' behaviour by comparing the election and referendum results in every constituency. For Assembly elections, Northern Ireland uses the single transferable vote system whereby voters rank candidates. This system which is designed to achieve proportional representation enables tactical voting. In order to take account of the general outlook of each constituency (whether it is more unionist or nationalist), we need to consider the first preference votes but also the total number of unionist, nationalist or other Members of the Legislative Assembly (MLAs) elected.

Table 2: Comparison between the $5^{\text {th }}$ May 2016 Assembly election and the $23^{\text {rd }}$ June EU referendum in Northern Ireland

\begin{tabular}{|c|c|c|c|c|c|c|}
\hline \multirow[t]{2}{*}{ Constituency } & \multicolumn{3}{|c|}{5 May 2016 NI Assembly election } & \multicolumn{3}{|c|}{23 June 2016 EU referendum } \\
\hline & Turnout & $\begin{array}{l}1^{\text {st }} \text { preference } \\
\text { vote }\end{array}$ & MLAs & Turnout & Remain & Leave \\
\hline Belfast East & $57.23 \%$ & DUP $14.8 \%$ & $\begin{array}{l}\text { DUP } 3 \\
\text { APNI } 2 \\
\text { UUP } 1\end{array}$ & $66.17 \%$ & $48.6 \%$ & $51.4 \%$ \\
\hline Belfast North & $52.48 \%$ & SF $15.57 \%$ & $\begin{array}{l}\text { DUP } 3 \\
\text { SF } 2 \\
\text { SDLP } 1\end{array}$ & $57.39 \%$ & $50.4 \%$ & $49.6 \%$ \\
\hline Belfast South & $54.25 \%$ & SF $14.17 \%$ & $\begin{array}{l}\text { DUP } 2 \\
\text { SF } 1 \\
\text { APNI } 1 \\
\text { SDLP } 1 \\
\text { Green } \\
1\end{array}$ & $66.88 \%$ & $69.5 \%$ & $30.5 \%$ \\
\hline Belfast West & $57.80 \%$ & PBPA $22.88 \%$ & $\begin{array}{l}\text { SF } 4 \\
\text { PBPA } 1 \\
\text { SDLP } 1\end{array}$ & $48.85 \%$ & $74.1 \%$ & $25.9 \%$ \\
\hline Lagan Valley & $53.19 \%$ & DUP $13.8 \%$ & $\begin{array}{l}\text { DUP } 3 \\
\text { UUP } 2 \\
\text { APNI } 1\end{array}$ & $66.25 \%$ & $46.9 \%$ & $53.1 \%$ \\
\hline
\end{tabular}




\begin{tabular}{|c|c|c|c|c|c|c|}
\hline South Down & $53.80 \%$ & SDLP $12.31 \%$ & $\begin{array}{l}\text { SDLP } 2 \\
\text { SF } 2 \\
\text { DUP } 1 \\
\text { UUP } 1\end{array}$ & $62.22 \%$ & $67.2 \%$ & $32.8 \%$ \\
\hline Mid-Ulster & $58.75 \%$ & SDLP $15.23 \%$ & $\begin{array}{l}\text { SF } 3 \\
\text { SDLP } 1 \\
\text { UUP } 1 \\
\text { DUP } 1\end{array}$ & $61.56 \%$ & $60.4 \%$ & $39.6 \%$ \\
\hline North Antrim & $52.93 \%$ & DUP $13.24 \%$ & $\begin{array}{l}\text { DUP } 3 \\
\text { TUV } 1 \\
\text { UUP } 1 \\
\text { SF } 1\end{array}$ & $64.67 \%$ & $37.7 \%$ & $60.3 \%$ \\
\hline East Antrim & $51.01 \%$ & DUP 18.22\% & $\begin{array}{l}\text { DUP } 3 \\
\text { UUP } 1 \\
\text { APNI } 1 \\
\text { SF } 1\end{array}$ & $64.95 \%$ & $44.8 \%$ & $55.2 \%$ \\
\hline North Down & $49.57 \%$ & DUP 19.72\% & $\begin{array}{l}\text { DUP } 3 \\
\text { UUP } 1 \\
\text { Green } \\
1 \\
\text { APNI } 1\end{array}$ & $67.33 \%$ & $52.4 \%$ & $47.6 \%$ \\
\hline South Antrim & $51.01 \%$ & DUP $14.27 \%$ & $\begin{array}{l}\text { DUP } 3 \\
\text { UUP } 1 \\
\text { APNI } 1 \\
\text { SF } 1\end{array}$ & $63.12 \%$ & $49.4 \%$ & $50.6 \%$ \\
\hline Strangford & $50.25 \%$ & UUP $14.31 \%$ & $\begin{array}{l}\text { DUP } 3 \\
\text { UUP } 2 \\
\text { APNI } 1\end{array}$ & $64.17 \%$ & $44.4 \%$ & $55.6 \%$ \\
\hline East Londonderry & $50.79 \%$ & DUP $13.46 \%$ & $\begin{array}{l}\text { DUP } 3 \\
\text { Ind } 1 \\
\text { SDLP } 1 \\
\text { SF } 1\end{array}$ & $59.69 \%$ & $52.0 \%$ & $48.0 \%$ \\
\hline Foyle & $56 \%$ & SF $12.68 \%$ & $\begin{array}{l}\text { SF } 2 \\
\text { SDLP } 2 \\
\text { PBPA } 1 \\
\text { DUP } 1\end{array}$ & $57.18 \%$ & $78.2 \%$ & $21.8 \%$ \\
\hline
\end{tabular}




\begin{tabular}{|c|c|c|c|c|c|c|}
\hline $\begin{array}{l}\text { Fermanagh and South } \\
\text { Tyrone }\end{array}$ & $64.55 \%$ & DUP $18.65 \%$ & $\begin{array}{l}\text { DUP } 2 \\
\text { UUP } 1 \\
\text { SF } 2 \\
\text { SDLP } 1\end{array}$ & $67.82 \%$ & $58.6 \%$ & $41.4 \%$ \\
\hline West Tyrone & $59.86 \%$ & DUP $11.98 \%$ & $\begin{array}{l}\text { SF } 3 \\
\text { SDLP } 1 \\
\text { DUP } 1 \\
\text { UUP } 1\end{array}$ & 61.69\% & $66.8 \%$ & $33.2 \%$ \\
\hline Upper Bann & $54.44 \%$ & DUP $17.49 \%$ & $\begin{array}{l}\text { DUP } 2 \\
\text { UUP } 2 \\
\text { SF } 2\end{array}$ & $63.64 \%$ & $47.4 \%$ & $52.6 \%$ \\
\hline Newry and Armagh & $59.32 \%$ & SF 14.29\% & $\begin{array}{l}\text { SF } 3 \\
\text { SDLP } 1 \\
\text { DUP } 1 \\
\text { UUP } 1\end{array}$ & $63.94 \%$ & $63.1 \%$ & $36.9 \%$ \\
\hline
\end{tabular}

Source: the electoral office for Northern Ireland ${ }^{17}$

It then appears that the turnout was generally higher in June than in May, Northern Ireland voters felt more concerned by the referendum than by the Assembly election. The Leave vote tended to be victorious in unionist-dominated constituencies but sometimes with a small majority: $50.6 \%$ in South Antrim, $51.4 \%$ in Belfast East. Nationalist constituencies tended to vote Remain in a much higher proportion than unionist ones voted Leave. However, two exceptions need to be noticed. In May, West Belfast voters clearly spurned Sinn Féin and gave the People Before Profit candidate the best score of all candidates in that election (22.88\% first preference). This party campaigned for leaving the EU from a left-wing perspective. In June, the Remain vote had its second highest score with $74.1 \%$ but the turnout was significantly down 8.95 percentage points. So it seems that PBPA supporters chose to stay at home rather than vote Leave along with DUP followers. In Foyle, where a People Before Profit MLA had also been elected, a similar but less pronounced trend could be noticed: with $78.2 \%$, the Remain vote had its best score, but the turnout had only marginally increased (from $56 \%$ to $57.18 \%$ ).

13 Once the votes were counted, Sinn Féin responded by a call for a border poll. Its relatively poor showing in the Assembly election the previous month and what, by contrast, had been described as "Arlene's triumph"18 seemed counter-balanced. But if the DUP appeared out of touch with the unionist population, nationwide it was vindicated: "only one party (except UKIP with 1 seat) in Westminster solidly supported what has now been shown to be the majority will of the British people: that party is the DUP. Maybe middle England is much more akin to the views of the DUP than many might like to think". ${ }^{19}$ 


\section{From one snap election to the next}

14 A few months later, while Arlene Foster had become First Minister, a major controversy developed, which turned into a full-blown political crisis. By the time she took office, an investigation was already under way into the Renewable Heat Incentive (RHI). Modelled on a similar scheme in England designed to encourage the shift to renewable energy sources such as wood pellets, it had one major flaw: payments made exceeded the money spent by $12 \% .^{20}$ So property owners were actually getting paid for heating their premises. The scheme had been in place since 2012, when Arlene Foster was the minister for trade, enterprise and investment. It soon became dubbed the "cash for ash" scandal when it transpired that whistle-blowers had tried to alert Arlene Foster about frauds on several occasions. One farmer was reported to be poised to earn $£ 1 \mathrm{~m}$ over a 20 -year period just for heating an empty shed. Before Christmas 2016, it was announced that the total bill of the RHI scheme would amount to $£ 490 \mathrm{~m}$, to be repaid entirely on Northern Ireland's budget while public services were already struggling with austerity measures imposed by Westminster.

Sinn Féin's initial reaction to the mounting criticism of Arlene Foster was surprised and confused. The party first asked her to step aside while an investigation took place. Then, “ with deep regret and reluctance", Martin McGuinness announced his resignation on 9 January, making a new election to the assembly inevitable. ${ }^{21}$ He blamed the First Minister's obstinacy, but he would have resigned in any case as he had been diagnosed with a rare genetic disease that proved to be fatal. He was hospitalised in Derry on 6 March and died on the $21^{\text {st }}$. McGuinness was succeeded by Michelle O'Neill on 23 January.

The snap election to the devolved assembly was held on 2 March 2017. Coming a mere 10 months after the previous one, a low turnout could have been expected. Exactly the opposite happened: at $64.8 \%$, it was the highest since 1998 . Undoubtedly, the Brexit vote and the border issue influenced voters' behaviour. The overall results show that Sinn Féin mostly benefited from this increased turnout at the polls.

Table 3: Northern Ireland Assembly election ( $2^{\text {nd }}$ March 2017) overall results

\begin{tabular}{|l|l|l|l|l|}
\hline Affiliation & Votes $\left(1^{\text {st }}\right.$ pref.) & Share & $+/-\%$ (from 2016) & Seats \\
\hline DUP & 225,413 & $28.1 \%$ & -1.1 & 28 \\
\hline SF & 224,245 & $27.9 \%$ & +3.9 & 27 \\
\hline SDLP & 95,958 & $11.9 \%$ & -0.1 & 12 \\
\hline UUP & 103,314 & $12.9 \%$ & +0.3 & 10 \\
\hline APNI & 72,717 & $9.1 \%$ & +2.1 & 8 \\
\hline Green & 18,527 & $2.3 \%$ & -0.4 & 2 \\
\hline TUV & 20,523 & $2.6 \%$ & -0.9 & 1 \\
\hline PBPA & 14,100 & $1.8 \%$ & -0.2 & 1 \\
\hline
\end{tabular}




\begin{tabular}{|l|l|l|l|l|}
\hline PUP & 5,590 & $0.7 \%$ & -0.2 & 0 \\
\hline Conservative & 2,399 & $0.3 \%$ & -0.1 & 0 \\
\hline Labour alternative & 2,009 & $0.3 \%$ & - & 0 \\
\hline UKIP & 1,579 & $0.2 \%$ & -1.3 & 0 \\
\hline CISTA $^{22}$ & 1,273 & $0.2 \%$ & - & 0 \\
\hline WP $^{23}$ & 1,261 & $0.2 \%$ & - & 0 \\
\hline Independent & 14,407 & $1.8 \%$ & -1.5 & 1 \\
\hline Total & 803,315 & 100.0 & & 90 \\
\hline
\end{tabular}

Source: Wikipedia ${ }^{24}$ have appealed to middle-ground voters. ${ }^{25}$ By so doing, they were calling to transgress the sectarian divide. This strategy failed, prompting the immediate resignation of the UUP leader Mike Nesbitt. In West-Belfast, the People Before Profit candidate lost his seat, even if his total number of first preference votes had increased slightly. In an assembly reduced from 108 to 90 members, the DUP got 28 seats, Sinn Féin 27, the SDLP 12 and the UUP 10. For the first time ever, with 39 to 38 , nationalist parties had a majority over unionist ones, while the DUP had one more seat than Sinn Féin. Some celebrated this election result as the awakening of nationalism: "Nationalism has awakened from its slumber, and in the process it has delivered the first electoral results that are reflective of the sharply changing demographic realities of the northern state". ${ }^{26}$ It is debatable whether the demographic realities of Northern Ireland had changed in the space of 10 months. What happened between the two elections was the unexpected referendum result which brought back to the fore old constitutional issues. Nationalists felt reinvigorated by the Remain victory in Northern Ireland which gave a sense of credibility to talks of a united Ireland while unionists were demoralised.

Then ensued a long stalemate which is still going on to this day: no executive has been formed. As in previous periods of suspension, the Members of the Legislative Assembly (MLAs) are still getting paid. At first, the main issues blocking the return of devolution were not the inquiry into the RHI fiasco, nor the prospect of a hard border with the Republic when the UK leaves the EU, but the demands set by Sinn Féin which the DUP refused to accept: an Irish Language Act, a bill of rights and same-sex marriage.

On 18 April, Theresa May took the world by surprise by announcing a snap general election for 8 June. Once again, the DUP and Sinn Féin were vindicated by the electorate. Out of 18 seats, the former won 10 and the latter 7. One independent unionist was also elected. The total share of seats between unionists and nationalists remained unchanged but the other two parties, the UUP and the SDLP, were out of the picture. A comparison between the two election results, three months apart, reveals that the duality nationalist $v s$ unionist had been reinforced after the Brexit referendum. 
Table 4: Comparison between the $2^{\text {nd }}$ March 2017 Assembly election and the $8^{\text {th }}$ June general election in Northern Ireland

\begin{tabular}{|c|c|c|c|c|c|}
\hline \multirow[t]{2}{*}{ Constituency } & \multicolumn{3}{|c|}{2 March 2017 NI Assembly election } & \multicolumn{2}{|c|}{$\begin{array}{l}8 \text { June } 2017 \text { general } \\
\text { election }\end{array}$} \\
\hline & Turnout & $\begin{array}{l}1^{\text {st }} \text { preference } \\
\text { vote }\end{array}$ & MLAs & Turnout & MPs \\
\hline Belfast East & $63.02 \%$ & DUP $14.88 \%$ & $\begin{array}{l}\text { DUP } 2 \\
\text { UUP } 1 \\
\text { APNI } 2\end{array}$ & $67.71 \%$ & DUP $55.76 \%$ \\
\hline Belfast North & $61.77 \%$ & SF $15.12 \%$ & $\begin{array}{l}\text { SF } 2 \\
\text { SDLP } 1 \\
\text { DUP } 2\end{array}$ & $67.56 \%$ & DUP $46.23 \%$ \\
\hline Belfast South & $63.96 \%$ & SF $17.67 \%$ & $\begin{array}{l}\text { SF } 1 \\
\text { SDLP } 1 \\
\text { APNI } 1 \\
\text { DUP } 1 \\
\text { Green } \\
1\end{array}$ & $66.31 \%$ & DUP $30.42 \%$ \\
\hline Belfast West & $66.76 \%$ & SF $17.14 \%$ & $\begin{array}{l}\text { SF } 4 \\
\text { PBPA } 1\end{array}$ & $65.41 \%$ & SF $66.71 \%$ \\
\hline Lagan Valley & $62.57 \%$ & DUP $17.82 \%$ & $\begin{array}{l}\text { DUP } 2 \\
\text { UUP } 1 \\
\text { APNI } 1 \\
\text { SDLP } 1\end{array}$ & $62.23 \%$ & DUP $59.56 \%$ \\
\hline South Down & $66.21 \%$ & SF $21.3 \%$ & $\begin{array}{l}\text { SF } 2 \\
\text { SDLP } 2 \\
\text { DUP 1 }\end{array}$ & $67.49 \%$ & SF $39.94 \%$ \\
\hline Mid-Ulster & $72.38 \%$ & SF $21.19 \%$ & $\begin{array}{l}\text { SF } 3 \\
\text { SDLP } 1 \\
\text { DUP } 1\end{array}$ & $68.59 \%$ & SF $54.51 \%$ \\
\hline North Antrim & $63.22 \%$ & SF $15.8 \%$ & $\begin{array}{l}\text { DUP } 2 \\
\text { TUV } 1 \\
\text { UUP } 1 \\
\text { SF } 1\end{array}$ & $64.21 \%$ & DUP 58.85\% \\
\hline
\end{tabular}




\begin{tabular}{|c|c|c|c|c|c|}
\hline East Antrim & $60.12 \%$ & DUP $16.03 \%$ & $\begin{array}{l}\text { DUP } 2 \\
\text { UUP } 2 \\
\text { APNI } 1\end{array}$ & $60.83 \%$ & DUP 57.34\% \\
\hline North Down & $60.12 \%$ & DUP $21.28 \%$ & $\begin{array}{l}\text { DUP } 2 \\
\text { UUP } 2 \\
\text { APNI } 1\end{array}$ & $61.04 \%$ & Ind. $41.21 \%$ \\
\hline South Antrim & $62.40 \%$ & SF $16.27 \%$ & $\begin{array}{l}\text { DUP } 2 \\
\text { UUP } 1 \\
\text { APNI } 1 \\
\text { SF } 1\end{array}$ & $63.44 \%$ & DUP $38.24 \%$ \\
\hline Strangford & $60.94 \%$ & DUP $16.04 \%$ & $\begin{array}{l}\text { DUP } 3 \\
\text { UUP } 1 \\
\text { APNI } 1\end{array}$ & $60.36 \%$ & DUP $62.03 \%$ \\
\hline East Londonderry & $62.69 \%$ & SF $13.97 \%$ & $\begin{array}{l}\text { DUP } 2 \\
\text { Ind. } 1 \\
\text { SDLP } 1 \\
\text { SF } 1\end{array}$ & $61.57 \%$ & DUP $48.07 \%$ \\
\hline Foyle & $65 \%$ & SF $20.63 \%$ & $\begin{array}{l}\text { SF } 2 \\
\text { SDLP } 2 \\
\text { DUP } 1\end{array}$ & $65.6 \%$ & SF $39.71 \%$ \\
\hline $\begin{array}{l}\text { Fermanagh and South } \\
\text { Tyrone }\end{array}$ & $72.61 \%$ & DUP $16.22 \%$ & $\begin{array}{l}\text { SF } 3 \\
\text { UUP } 1 \\
\text { DUP } 1\end{array}$ & $76.08 \%$ & SF $47.17 \%$ \\
\hline West Tyrone & $69.89 \%$ & SF $17.4 \%$ & $\begin{array}{l}\text { SF } 3 \\
\text { SDLP } 1 \\
\text { DUP } 1\end{array}$ & $68.23 \%$ & SF $50.72 \%$ \\
\hline Upper Bann & $62.54 \%$ & SF $15.94 \%$ & $\begin{array}{l}\text { DUP } 2 \\
\text { UUP } 1 \\
\text { SDLP } 1 \\
\text { SF } 1\end{array}$ & $64.15 \%$ & DUP $43.53 \%$ \\
\hline Newry and Armagh & $69.41 \%$ & DUP $17.77 \%$ & $\begin{array}{l}\text { SF } 3 \\
\text { SDLP } 1 \\
\text { DUP } 1\end{array}$ & $68.87 \%$ & SF $46.97 \%$ \\
\hline
\end{tabular}

Source: the electoral office for Northern Ireland ${ }^{27}$

21 We may note the distortion effect caused by the first-past-the-post voting system which mainly benefited the DUP. Constituencies like Belfast North and Belfast South do not have 
a unionist majority yet returned DUP MPs to Westminster. In any case, the fact that the border had become the most talked about issue did not ease off the polarisation of the Northern Ireland electorate. Theresa May's difficulties became the DUP's opportunity: suddenly, its 10 Members of Parliament mattered. They were Kingmakers. Finding itself catapulted from the outer fringes to the centre of British power, the Northern Irish party saw a way to redress its previous misfortunes with the unplanned RHI scandal in December and its relative loss of influence on its electorate in March.

When Arlene Foster negotiated a $£ 1 b n$ deal with Theresa May, ${ }^{28}$ Sinn Féin reacted angrily. Gerry Adams, who had taken back a front-stage role since the death of Martin McGuinness, called it a "blank cheque for a Tory Brexit which threatens the Good Friday Agreement". ${ }^{29}$ The threat to the peace process and/or the Good Friday Agreement, is an argument that he has used on many occasions, for example when he was questioned by the police in May 2014 about his alleged involvement in the 1972 murder of a widow, mother of 10 children, accused by the IRA of being an informer. ${ }^{30}$ It seems that these communication tools used by Sinn Féin at regular intervals were adopted unquestioningly by the international press, for instance Le Monde:

Si le Royaume-Uni choisit de sortir du marché unique européen - l'option privilégiée jusqu'à présent par Mme May -, le rétablissement d'une frontière entre l'Ulster et la République d'Irlande pourrait être nécessaire, afin de contrôler l'immigration et le commerce. Les républicains n'apprécieraient alors pas du tout de voir leur île à nouveau morcelée, alors que les signes visibles d'une frontière ont aujourd'hui complètement disparu. ${ }^{31}$

Or L'Humanité: «En cherchant à constituer une alliance avec les extrémistes unionistes, Theresa May risque de rouvrir les plaies de la guerre civile ${ }^{32}$."

\section{The Conservative and Unionist Party}

But this is not the first time the Conservatives have had to make deals with unionist MPs. On 13 June, John Major warned Theresa May that a deal with the DUP could put peace in Northern Ireland at risk:

A fundamental part of that peace process is that the UK government needs to be impartial between all the competing interests in Northern Ireland," he said. "The danger is that however much any government tries, they will not be seen to be impartial if they are locked into a parliamentary deal, at Westminster, with one of the Northern Ireland parties. ${ }^{33}$

Yet when he was Prime Minister, from 1993 on, a series of by-election defeats rendered his political survival reliant on support from the nine Ulster Unionist MPs in Parliament. He struck up a $£ 10 \mathrm{~m}$ deal with them to subsidise heavy electricity users and promised them an electricity inter-connector cable to Scottish Power ${ }^{34}$. In his 1995 Conservative Party Conference speech, he reminded: "We are the Conservative and Unionist Party ${ }^{35}$ ".

The press also lambasted Theresa May for striking a deal with a party linked to loyalist terrorism and to the bigoted Orange Order. Even if those links are not to be denied, it has to be stressed that the supposedly middle-of-the-road UUP has had a much more ancient and established relationship with paramilitaries and the Orange brotherhoods than the DUP, if only because the DUP is more recent. Without going into the details of the creation of the UVF by Sir Edward Carson in 1912, we can point to the fact that the setting up of the current UVF in 1965 is supposed to have taken place during a meeting at the 
UUP headquarters in Glengall Street in Belfast, organised by members of the Northern Ireland cabinet who wanted to undermine $0^{\prime} \mathrm{Neill}^{36}$. As for the Orange Order, the links with the UUP are also very old ${ }^{37}$.

So, when Gerry Adams says that the DUP-Tory deal puts the Good Friday Agreement in danger, he seems to be implying that if Sinn Féin does not get its way, the IRA will go back on a war footing. This could be seen as a form of blackmail but perhaps efficiency matters more than morals in politics. We may then want to ascertain the plausibility of this veiled threat, perhaps it is pure rhetoric. In October 2015, the Police Service of Northern Ireland (PSNI), together with the MI5, published a report on paramilitary groups at the demand of the Northern Ireland Secretary. This report settled a serious political crisis provoked by a series of murders. On 5 May 2015, IRA commander Gerard 'Jock' Davison was shot and killed in front of his house in the republican Markets area of Belfast. In the neighbourhood, it was rumoured that the perpetrator was a former IRA member named Kevin McGuigan. He was killed by two masked men on 12 August. A crisis developed when the police claimed that McGuigan's assassination had been sanctioned by the IRA at the highest level, implying that the IRA was still in existence, a suspicion confirmed in the report published in October. In fact, the report issued that "All of the main paramilitary groups operating during the period of the Troubles remain[ed] in existence" ${ }^{38}$ However, these groups did not really represent a threat to peace as the report stated: "It is our firm assessment that, to different degrees, the leaderships of the main paramilitary groups are committed to peaceful means to achieve their political objectives". ${ }^{39}$

In any case, we may seriously doubt the Provisional IRA's capacity to resume its activities, even to the level of 1996-1997. It would take extraordinary circumstances, far beyond a pact between the DUP and the Conservative Party. We should perhaps be warier of the UDA, the UVF, the Red Hand Commando and the myriad of offshoots and splinter groups who are constantly in the news, organising bonfires and parades, putting up flags on lamp-posts, painting murals, rioting, selling drugs and carrying out punishment beatings on drug dealers, intimidating foreigners and doing voluntary community work, racketeering businesses and canvassing government officials for subsidies. If a referendum on Irish unity were to be carried out, those loyalist paramilitary groups could very well find their real purpose, should the results not be to their liking. However, even if the people of Northern Ireland wanted to stay in the EU, even if nationalists have now a majority over unionists in the temporarily out-of-order Northern Ireland Assembly, we should not jump to conclusions regarding the result of such a referendum.

Since 1998, the Queen's University of Belfast and Ulster University have carried out surveys, called 'Northern Ireland Life and Times Surveys', covering a wide range of issues on a yearly basis. On the question of what the long-term policy for Northern Ireland should be, the results have always shown remarkable consistency. ${ }^{40}$ In $2016,54 \%$ of respondents thought it should remain part of the UK with a devolved government, 19\% thought it should reunify with the rest of Ireland, $12 \%$ opted for remaining part of the UK with direct rule. In 2015 , the answers to the same question were $51 \%, 14 \%$ and $19 \%$. In 2014 , they were $50 \%, 17 \%$ and $16 \%$. On a TV program shown in April 2018, academic Dr Paul Nolan said that a catholic majority in Northern Ireland was possible by $2021 .{ }^{41}$ But a catholic majority does not necessarily mean that a majority would vote for a united Ireland. 


\section{Conclusion}

30 struggles for the balance of power between the two main political parties of Northern Ireland. In May 2016, Sinn Féin seemed in a difficult situation, having lost votes and seats in the local assembly. Then the victory of the Remain vote locally was seen as a defeat for the DUP. In March 2017, nationalists gained a majority over unionists at Stormont for the first time. But in June, the DUP regained a semblance of control by offering their backing to the Prime Minister. These small changes must not hide the fact that the political landscape of Northern Ireland if at all shows very little evolution.

31

It is a truism to say that this is a deeply divided society. Constant bickering over the display of flags and emblems, parades, marching bands and bonfires, commemorations of all kinds, is but a reflection of social structures dominated by socio-religious segregation. Northern Ireland is political and cultural world of its own. Its dual educational system, its political life, the visible signs of its conflictual past (wall murals, painted kerb-stones, peace-lines and physical separations) do not exist anywhere else in the British Isles. Yet, if unionists and nationalists generally agree that Northern Ireland should for the foreseeable future remain part of the UK with a devolved government, we may wonder what really separates them. This is one first paradox.

The second paradox is that Northern Ireland is remarkably stable and that instability comes from the outer world. The Brexit vote went against all the stereotypes: the English are supposed to be pragmatic and rational, the Irish are supposed to be passionate and disorderly. By voting for leaving the European Union, English voters have shown that constitutional change is possible, or is it? The conundrum of the border issue has highlighted the fact that Ireland was partitioned nearly one hundred years ago. The question of Irish reunification has come back to haunt British politics, it attracts attention European-wide. Nationalist expectations are then raised and unionist fears are heightened. If Scottish nationalists get their way and achieve independence, this will also have a strong impact on the Irish situation. In a nutshell, there is no internal threat to the peace process in Northern Ireland but external factors have the potential to upset it.

Michel Savaric has been a lecturer at the University of Franche-Comté since 2002 where he is a member of the Centre de Recherches Interdisciplinaires et Transculturelles (CRIT). He recently collaborated to Sociétés face à la terreur, edited by Nicolas Bonnet, Pierre-Paul Grégorio, Nathalie Le Bouëdec, Alexandra Palau, Marc Smith, and published by Orbis Tertius, 2017. His current research focuses on the history of Northern Ireland.

\section{BIBLIOGRAPHY}

Albert, Eric, « Royaume-Uni : Theresa May n'a toujours pas trouvé d'accord avec les unionistes nord-irlandais », Le Monde, 13 juin 2017.

Revue Française de Civilisation Britannique, XXIII-2 | 2018 
BBC News Northern Ireland, "RHI scandal: RHI 'cash for ash' scandal to cost NI taxpayers $£ 490 \mathrm{~m}$ ”, 23 December 2016, http://www.bbc.com/news/uk-northern-ireland-38414486, accessed 23 December 2016.

Belfast Telegraph, "I'll be having a drink tonight: Stephen Nolan to party after week of RHI revelations", 16 December 2016.

Bodkin, Henry, "Who are the DUP MPs who now hold the balance of power", The Telegraph, 10 June 2017.

Chabas, Charlotte, « Le PUD, le petit parti nord-irlandais qui permet à Theresa May d'avoir une majorité absolue », Le Monde, 9 June 2017.

Donnelly, Chris, “Nationalism Bites Back”, Slugger O’Toole, 4 March 2017, https:// sluggerotoole.com/2017/03/04/nationalism-bites-back/, accessed 4 March 2017.

Ferguson, Amanda, “Northern Ireland's DUP surge, could help Britain's May reach majority", Reuters, 9 June 2017.

Ferguson, Kate, "Armed drills, terror endorsements and anti-gay rights: The chequered links of Ian Paisley party which has become Theresa May’s kingmakers”, The Daily Mail, 10 June 2017.

Fianna Fáil The Republican Party, "Sinn Féin role in northern Cash-for-Ash affair raises serious questions”, 28 January 2017, https://www.fiannafail.ie/sinn-fein-role-in-northern-cash-for-ashaffair-raises-serious-questions/, accessed 28 January 2017.

Frances, Diane, «Qu'est-ce que le DUP, ce parti sulfureux avec lequel Theresa May a passé un accord de gouvernement », The Huffington Post, 26 June 2017, http://

www.huffingtonpost.fr/2017/06/26/quest-ce-que-le-dup-ce-parti-sulfureux-avec-lequel-theresamay-a-passe-un-accord_a_23002343/

Gordon, Gareth, “'Catholic majority possible' in NI by 2021”, BBC News, 19 April 2018, https:// www.bbc.com/news/uk-northern-ireland-43823506, accessed 11 June 2018

Hewitt, John, The Collected Poems of John Hewitt (1987), Belfast: Blackstaff Press. Irish News, 19 December 2016, “Arlene Foster survives vote of no confidence over RHI scandal” Irish News, 9 June 2017, "So 'who are the DUP?' was the most asked question on Google" Irish Times, 26 June 2017, “DUP deal threatens Belfast Agreement, says Gerry Adams” Lemahieu, Thomas, « Les tories mettent l'Irlande du Nord en danger », L'Humanité, 12 juin 2017. Major, John, 1995 Conservative Conference Speech, http://www.ukpol.co.uk/john-major-1995conservative-party-conference-speech/

McBride, Sam, "SF flip-flops wildly over backing public inquiry into RHI scandal”, The News Letter, 3 January 2017.

McDonald, Henry, "Gerry Adams freed without charge after questioning over McConville case", Guardian, 4 May 2014.

McDonald, Henry, "Sinn Féin calls for vote on Irish reunification if UK backs Brexit", Guardian, 11 March 2016.

McIntosh, Gillian, The Force of Culture: Unionist Identities in Twentieth Century Ireland (1999), Cork: Cork University Press.

Moloney, Ed, A Secret History of the IRA (2007), London: Penguin. 
Moriarty, Gerry, "SDLP believes best hope for NI election is pact with UUP”, Irish Times, 1 March 2017.

Northern Ireland Life and Times, http://www.ark.ac.uk/nilt/ accessed 11 June 2018.

Novosel, Tony, Northern Ireland's Lost Opportunity: The Frustrated Promise of Political Loyalism (2013), London: Pluto Press.

"Paramilitary Groups in Northern Ireland: An Assessment Commissioned by the Secretary of State for Northern Ireland on the Structure, Role and Purpose of Paramilitary Groups Focusing on those which Declared Ceasefires in order to Support and Facilitate the Political Process, 19 October 2015", https://www.gov.uk/government/uploads/system/uploads/attachment_data/ file/469548/Paramilitary_Groups_in_Northern_Ireland_-Oct_2015.pdf accessed 20 October 2015.

Pasha-Robinson, Lucy, "Why is the DUP so controversial? The party's stances on abortion, gay marriage and climate change explained", The Independent, 9 June 2017.

Syal, Rajeev, "From climate denial to abortion: six DUP stances you should know about", Guardian , 9 June 2017.

Syal, Rajeev and Walker, Peter, "John Major: Tory-DUP deal risks jeopardising Northern Ireland peace”, Guardian, 13 June 2017.

The Electoral Office Northern Ireland, http://www.eoni.org.uk/Elections/Election-results-andstatistics/Election-results-and-statistics-2003-onwards/Elections-2017/UK-ParliamentaryElection-2017-Results, accessed 10 June 2018.

Turgon, “Arlene's triumph: time for others to reconsider their pitches and where that horse is", Slugger O'Toole, 7 May 2016, http://sluggerotoole.com/2016/05/07/arlenes-triumph-time-forother-to-reconsider-their-pitches/, accessed 7 May 2016.

Turgon, "Referendum result: DUP in touch with Middle England", Slugger O'Toole, 24 June 2016, https://sluggerotoole.com/2016/06/24/referendum-result-dup-in-touch-with-middle-england/, accessed 24 June 2016

Wikipedia, https://en.wikipedia.org/wiki/Northern_Ireland_Assembly_election,_2017, accessed 10 June 2018.

Wynn Davies, Patricia, “Ulster Unionist MPs “will keep Major in power”, The Independent, 9 July 1993.

\section{NOTES}

1. Helena Horton, “'We are all Brenda': Hilarious video of shocked woman reacting to General Election news sparks empathy", The Telegraph, $18^{\text {th }}$ April 2017, https://www.telegraph.co.uk/ news/2017/04/18/brenda-hilarious-video-shocked-woman-reacting-general-election/, accessed $11^{\text {th }}$ June 2018.

2. "So 'who are the DUP?' was the most asked question on Google", Irish News, $9^{\text {th }}$ June 2017.

3. Charlotte Chabas, «Le PUD, le petit parti nord-irlandais qui permet à Theresa May d'avoir une majorité absolue ", Le Monde, $9^{\text {th }}$ June 2017. The DUP, that small political party from Northern Ireland which enables Theresa May to have a majority in Parliament.

4. Diane Frances, «Qu'est-ce que le DUP, ce parti sulfureux avec lequel Theresa May a passé un accord de gouvernement", The Huffington Post, 26th June 2017, http:// www.huffingtonpost.fr/2017/06/26/quest-ce-que-le-dup-ce-parti-sulfureux-avec-lequel-theresamay-a-passe-un-accord_a_23002343/, accessed $26^{\text {th }}$ June 2017. 
5. Rajeev Syal, "From climate denial to abortion: six DUP stances you should know about", The Guardian, $9^{\text {th }}$ June 2017.

6. Lucy Pasha-Robinson, "Why is the DUP so controversial? The party's stances on abortion, gay marriage and climate change explained", The Independent, $9^{\text {th }}$ June 2017.

7. Henry Bodkin, "Who are the DUP MPs who now hold the balance of power", The Telegraph, $10^{\text {th }}$ June 2017.

8. Kate Ferguson, "Armed drills, terror endorsements and anti-gay rights: The chequered links of Ian Paisley party which has become Theresa May's kingmakers", The Daily Mail, $10^{\text {th }}$ June 2017.

9. John Hewitt, The Collected Poems of John Hewitt (1987), Belfast: Blackstaff Press, p. 140.

10. "Paisley - From Troublemaker to Peacemaker" was the title of a documentary released on RTÉ, in the Republic of Ireland, in January 2008.

11. Paul Dixon, Northern Ireland: The Politics of War and Peace (2008), Basingstoke: Palgrave Macmillan, p. 113.

12. As we will see further, it is debatable whether the UUP, historically linked to the UVF (Ulster Volunteer Force), really is more moderate than the UUP. As for the distinction between constitutional nationalism and republicanism, we may wonder whether it is still relevant since Sinn Féin accepted the 'principle of consent' (i.e. Northern Ireland will remain British so long as a majority wishes it to be so) when it signed up to the Good Friday agreement.

13. Amanda Ferguson, "Northern Ireland's DUP surge, could help Britain's May reach majority", Reuters, $9^{\text {th }}$ June 2017.

14. Acronyms: DUP: Democratic Unionist Party, SF: Sinn Féin, UUP: Ulster Unionist Party; SDLP: Social Democratic and Labour Party, APNI: Alliance Party of Northern Ireland, TUV: Traditional Unionist Voice, PBP: People Before Profit, UKIP: United Kingdom Independence Party, PUP: Progressive Unionist Party.

15. Henry McDonald, "Sinn Féin calls for vote on Irish reunification if UK backs Brexit", The Guardian, $11^{\text {th }}$ March 2016.

16. Department of Foreign Affairs and Trade, "Remarks by Ambassador Mulhall, House of Commons, $10^{\text {th }}$ February 2016", https://www.dfa.ie/irish-embassy/great-britain/news-andevents/2016/ambassador-mulhall-niac-ni-and-eu-referendum/, accessed $21^{\text {st }}$ May 2018.

17. http://www.eoni.org.uk/Elections/Election-results-and-statistics/Election-results-andstatistics-2003-onwards/Elections-2016/ accessed 22 ${ }^{\text {nd }}$ May 2018.

18. Turgon, "Arlene's triumph: time for others to reconsider their pitches and where that horse is", Slugger O'Toole, $7^{\text {th }}$ May 2016, http://sluggerotoole.com/2016/05/07/arlenes-triumph-timefor-other-to-reconsider-their-pitches/

19. Turgon, "Referendum result: DUP in touch with Middle England", Slugger O'Toole, $24^{\text {th }}$ June 2016, https://sluggerotoole.com/2016/06/24/referendum-result-dup-in-touch-with-middleengland/

20. "RHI scandal: RHI 'cash for ash' scandal to cost NI taxpayers $£ 490 \mathrm{~m}$ ", BBC News Northern Ireland, $23^{\text {rd }}$ December 2016, http://www.bbc.com/news/uk-northern-ireland-38414486

21. Cormac McQuinn, “Martin McGuinness resigns: 'My health has absolutely nothing to do with this"', Belfast Telegraph, $9^{\text {th }}$ January 2017.

22. Cannabis Is Safer Than Alcohol.

23. The Workers' Party.

24. accessed $10^{\text {th }}$ June 2018.

25. Gerry Moriarty, "SDLP believes best hope for NI election is pact with UUP", The Irish Times, $1^{\text {st }}$ March 2017.

26. Chris Donnelly, "Nationalism Bites Back", Slugger O'Toole, $4^{\text {th }}$ March 2017, https:// sluggerotoole.com/2017/03/04/nationalism-bites-back/ accessed $4^{\text {th }}$ March 2017. 
27. The Electoral Office for Northern Ireland, http://www.eoni.org.uk/Elections/Electionresults-and-statistics/Election-results-and-statistics-2003-onwards/Elections-2017/UKParliamentary-Election-2017-Results accessed $10^{\text {th }}$ June 2018.

28. Andy Boal, “Tory-DUP Deal Reached”, https://sluggerotoole.com/2017/06/26/tory-dup-dealreached/ accessed $10^{\text {th }}$ June 2018.

29. "DUP deal threatens Belfast Agreement, says Gerry Adams", The Irish Times, $26^{\text {th }}$ June 2017.

30. Henry McDonald, "Gerry Adams freed without charge after questioning over McConville case", The Guardian, $4^{\text {th }}$ May 2014.

31. "If the UK chooses to exit the EU single market - Ms May's preferred option so far - the reestablishment of a border between Ulster and the Republic of Ireland may be necessary to control immigration and trade. Republicans would not appreciate at all seeing their island split up again while the visible signs of a border have now completely disappeared", Eric Albert, «Royaume-Uni: Theresa May n'a toujours pas trouvé d'accord avec les unionistes nordirlandais », Le Monde, 13 juin 2017.

32. "By seeking an alliance with unionist extremists, Theresa May risks reopening the wounds of the civil war", Thomas Lemahieu, « Les tories mettent l'Irlande du Nord en danger ", L'Humanité, 12 juin 2017.

33. "John Major: Tory-DUP deal risks jeopardising Northern Ireland peace", The Guardian, $13^{\text {th }}$ June 2017.

34. Patricia Wynn-Davies, "Ulster Unionist MPs 'will keep Major in power”, The Independent, $9^{\text {th }}$ July 1993.

35. John Major, 1995 Conservative Conference Speech, http://www.ukpol.co.uk/johnmajor-1995-conservative-party-conference-speech/. Even if this was aimed at Scottish nationalists, it was music to protestant ears in Northern Ireland. Major's dependence on the UUP is arguably what explains the extremely slow pace of the initial stages of the peace process and the collapse of the IRA ceasefire on 9 February 1996. The decision to reinstate the ceasefire was made when it became clear that the Tories would lose the election. See Ed Moloney, A Secret History of the IRA (2007), London: Penguin, p. 457.

36. Tony Novosel, Northern Ireland's Lost Opportunity: The Frustrated Promise of Political Loyalism (2013), London: Pluto Press, p. 15.

37. All the members of the Stormont government between 1921 and 1972 were Orangemen and Orange parades were elevated to the status of State rituals during the first fifty years of Northern Ireland's existence. See Gillian McIntosh, The Force of Culture: Unionist Identities in Twentieth Century Ireland (1999), Cork: Cork University Press.

38. "Paramilitary Groups in Northern Ireland: An Assessment Commissioned by the Secretary of State for Northern Ireland on the Structure, Role and Purpose of Paramilitary Groups Focusing on those which Declared Ceasefires in order to Support and Facilitate the Political Process, $19^{\text {th }}$ October 2015", https://www.gov.uk/government/uploads/system/uploads/attachment_data/ file/469548/Paramilitary_Groups_in_Northern_Ireland_-Oct_2015.pdf accessed 20 th October 2015.

39. Ibid.

40. http://www.ark.ac.uk/nilt/ accessed $11^{\text {th }}$ June 2018.

41. Gareth Gordon, “'Catholic majority possible' in NI by 2021", BBC News, 19 $9^{\text {th }}$ April 2018, https:// www.bbc.com/news/uk-northern-ireland-43823506 accessed $11^{\text {th }}$ June 2018. 


\section{ABSTRACTS}

Following in the wake of the Brexit vote when a majority of Northern Ireland electors voted to remain after the DUP had campaigned for leaving the EU, it really did seem that the hardline unionist party was gradually losing its grip on local politics. The prospect of a united Ireland was immediately seized upon by Sinn Féin as a way to solve the border issue created by the Brexit vote. Then Theresa May unexpectedly decided to call for a snap general election on $8^{\text {th }}$ June. Once again, Sinn Féin and the DUP increased their share of the vote. But the DUP reversed its gradual loss of influence while suddenly becoming central to British politics when it brokered a deal with the Prime Minister. The dominant view in the British and international media was then that the deal put the Northern Ireland peace process at risk. The point of this paper is to question this assumption which seems to imply that simply because Sinn Féin does not get its way, the IRA will revert back to an armed campaign. The question would rather be whether the IRA is still in a capacity to do so. It may also be argued that the increased feeling of insecurity among the loyalist community represents an equal threat to the stability of the region. At the same time, we will explore all the apparent paradoxes revealed by the Northern Ireland elections since June 2016.

S'inscrivant dans la foulée du référendum sur le Brexit où la majorité des électeurs nordirlandais avaient voté pour rester alors que le DUP avait fait campagne pour quitter l'UE, il semblait bien que le parti unioniste extrémiste était en train de perdre de son influence sur la politique locale. La perspective d'une Irlande unie a été immédiatement brandie par le Sinn Féin comme solution possible au problème de la frontière posé par le vote pour le Brexit. Puis Theresa May a décidé, à la surprise générale, de provoquer des législatives anticipées pour le 8 juin. Une fois de plus, le Sinn Féin et le DUP ont augmenté leur score. Mais le DUP a regagné l'influence perdue en devenant un élément central de la vie politique britannique lorsqu'il a négocié un accord avec la première ministre. Le point de vue dominant dans les médias britanniques et internationaux était alors que cet accord mettait en danger le processus de paix. Le but de cet article sera de questionner cette assertion qui semble signifier que si le Sinn Féin n'obtient pas ce qu'il désire, l'IRA retournera à la violence politique. La question serait plutôt de savoir si l'IRA est toujours en capacité de reprendre les armes. On peut également avancer qu'un sentiment accru d'insécurité parmi la communauté loyaliste représente tout autant une menace pour la stabilité de la région. En même temps, nous explorerons tous les apparents paradoxes révélés par les élections en Irlande du Nord depuis juin 2016.

\section{INDEX}

Mots-clés: processus de paix, Irlande du Nord, Brexit

Keywords: peace process, Northern Ireland, DUP-SF partnership, DUP-Tory deal, Brexit 


\section{AUTHOR}

\section{MICHEL SAVARIC}

University of Franche-Comté, Centre de Recherches Interdisciplinaires et Transculturelles (CRIT) 